\title{
Speciation in flowering plants: an overview
}

\author{
Shivanna K.R. \\ Ashoka Trust for Research in Ecology and the Environment, Srirampura, Jakkur Post, \\ Bengaluru, Karnataka - 560 064, India. \\ E-mail: shivannakr40@gmail.com
}

\begin{abstract}
The great biological diversity prevailing on the planet earth is the result of speciation taking place since life originated over 3.5 billion years ago. Speciation is the result of natural selection acting on heritable variations. The common definition of species, generally practiced by taxonomists, is a group of individuals that is morphologically distinct from other groups. The literature on speciation is extensive and most of the reviews cover one or another aspect of speciation rather than the entire field. In this review, an attempt is made to provide an overview on speciation, particularly the definitions, requirements, various modes and pathways including an outlook proposed on the rate of speciation in the coming decades due to ongoing human-induced environmental and biological changes, keeping in view the non-specialists.
\end{abstract}

Key words: Allopatric mode, Floral traits, Hybridization, Pollinator-driven speciation, Polyploidy, Sympatric mode.

\section{Introduction}

The planet Earth holds an enormous biological diversity made up of plants, animals, and other eukaryotes and prokaryotes. Until Darwin proposed his theory of evolution, all life forms present on the planet were believed to be created by God and they were thought to be immutable over the course of time. Following the publication of Darwin's theory of evolution (Darwin, 1859), the creationist concept was gradually replaced by an evolutionary concept which explained the origin of new species as a result of natural selection acting on heritable variations. Over the years, evolution

Received: 03.07.2020; Revised \& Accepted: 06.12.2020

Published Online: 31.12 .2020 has become one of the most important concepts in biology. According to the noted geneticist, Theodosius Dobzhansky (1937) 'Nothing in biology makes sense except in the light of evolution'. The static species concept of Linnaeus has now been replaced by a dynamic species concept and the population has become the unit of speciation (see Stebbins, 1950; Hey et al., 2005; Lexer \& Widmer, 2008). Thus, the biological diversity currently prevailing on Earth is the result of evolutionary processes operating since life originated over 3.5 billion years ago (Lazcano \& Miller, 1996; Patel et al., 2015). The best working estimate of the number of eukaryotic species present on the planet ranges from 8.7 million to 12 million, of which only about 1.2 million have so far been scientifically documented (see Mora et al., 2011; Raven, 2020). Rapid diversification of angiosperms has been the subject of continuous debate for more than 100 years (see Crane et al., 2000; Crepet \& Niklas, 2009; Magallón \& Castillo, 2009; Smith et al., 2011; Bao et al., 2019). Based on fossil evidence, the origin of angiosperms was traditionally considered to be in the Cretaceous period ranging from 110 to 135 million years ago. However, in recent years, based on molecular data, the origin of angiosperms has been pushed back to the late Triassic period about 210 million years ago (see Coiro et al., 2019, Li et al., 2019, Janssens et al., 2020, van der Kooi \& Ollerton, 2020).

There is no definition of species that is universally accepted or valid under all circumstances (Mayr, 1942; Simpson, 1951; Queiroz, 2007). The morphological species concept, practiced by most taxonomists, defines species as a group of individuals that is morphologically distinct from other groups. 
According to the biological species concept (Mayr, 1942) a species is made up of 'groups of naturally or potentially interbreeding individuals which are reproductively isolated from other such groups'. Thus, morphological dissimilarity and reproductive isolation are the two major criteria for distinguishing species. The biological species concept, however, is difficult to apply as a routine concept since there are practical difficulties to investigate reproductive isolation of a potential new species with related species. Further, reproductive isolation is not absolute in many of the plant species; some hybrids do form between well-defined related species, although most of them may not establish as new species. Also, a number of molecular studies have shown gene flow is quite common between populations and species. In fact, as discussed later, speciation through hybridization is considered as one of the major pathways as far as plants are concerned. Thus, the biological species concept has limitations for routine use in plants, although it is prevalent in animals (Grant, 1981). Generally, taxonomists who erect new species continue to use a morphological definition of species.

There are two other species concepts that are not very prevalent in the literature. According to the phylogenetic species concept 'the smallest diagnosable cluster of individual organisms within which there is a parental pattern of ancestry and descent' (Eldredge \& Cracraft, 1980) is considered a species. It tries to define species by their relationships to other species based on their genealogical relationships. A group of individuals that includes all the descendants of one common ancestor is referred to as a monophyletic group. According to Wiley's (1978) evolutionary species concept, a species is a lineage of interbreeding organisms, reproductively isolated from other lineages, that has a beginning (i.e., speciation through reproductive isolation from the parent population), an end (i.e., either with extinction or with its branching into one or more descendants), and a distinct evolutionary trajectory.

Speciation is a prolonged and complex process and can take hundreds or thousands of generations.
Unlike many other biological events, most of the evidence related to speciation is indirect and cannot be easily replicated or demonstrated. A general understanding of speciation is largely based on field observations and analysis. Speciation has been discussed extensively since the 1930s by a number of investigators and a vast literature has accumulated on the subject (e.g., Dobzhansky, 1937; Mayr, 1942; Stebbins, 1950; Grant, 1981; Fenster et al., 2004; Hey et al., 2005; Rundle \& Nosil, 2005; Rieseberg \& Willis, 2007; Abbott et al., 2008; Cozzolino \& Scopece, 2008; Lexer \& Widmer, 2008; Kay \& Sargent, 2009; Soltis \& Soltis, 2009; Ferrer \& Good, 2012; Yuan et al., 2013; Levin, 2019). Most of the reviews are confined to comprehensive discussion covering one specific aspect of speciation, such as modes of speciation (Butlin et al., 2008), pollinatordriven speciation (Hoballah et al., 2007; Kay \& Sargent 2009; Xu et al., 2012a,b; van der Niet et al., 2014), reproductive isolation in general (Lexer \& Widmer, 2008) or in relation to floral specialization (Ambruster \& Muchhala, 2009), ecological adaptation (Rundle \& Nosil, 2005; Sobel et al., 2010), polyploidy (Wood et al., 2009; Laport \& Ng, 2017; Pelé et al., 2018), hybridization (Ferguson \& Sang, 2001; Gross \& Riesenberg, 2005; Mallet, 2007; Rieseberg \& Willis, 2007; Soltis \& Soltis, 2009; Alix et al., 2017) and also speciation in the coming decades due to ongoing human-induced environmental changes (see Thomas, 2015; Levin, 2019). Hardly any review covers the whole concept of speciation. Although speciation is basic to all branches of biology, not all botanists, particularly in structural and functional disciplines, are familiar with basic concepts of speciation. An attempt is made here to give an overview of speciation in angiosperms, the most successful and highly diverse group amongst land plants without going too deep into all the complexities. This overview is essentially aimed to non-specialists and the references cited provide links to more comprehensive accounts on different aspects of speciation. Some terminologies associated with speciation are explained in Appendix 1. 


\section{Major requirements for speciation}

Heritable variations, natural selection and reproductive isolation are the basic requirements for speciation. Presence of heritable variations is the primary requirement (Hoffman \& Merilä, 1999). Mutations are the source of heritable variations and thus are the raw materials for speciation. Recombination during meiosis brings about additional variations by reshuffling of the mutated genes. Chromosomal and epigenetic changes, particularly under ecological stresses, also induce variations (Tsaftaris \& Polidoros, 2000).

Natural selection acts on heritable variation and is the main operating force for speciation. Natural selection operates on mutations in three ways: if the mutation improves the fitness of the individuals under the prevailing environment, such mutants produce more progeny when compared to those without the mutated allele and gradually the individuals of the original population would get replaced with the mutants. If the mutation affects the fitness negatively, such individuals are less efficient in producing the progeny and they eventually get eliminated. If the mutation has no immediate effect on the fitness of the progeny, they are retained in the population until they affect the fitness positively or negatively. The action of natural selection is stronger when there is a change in the habitat; this generally happens when the individuals get dispersed to a new habitat (Rundle \& Nosil, 2005; Sobel et al., 2010).

Reproductive isolation primarily depends on some mechanism that prevents gene flow (movement of genes through space) between individuals within a population or between populations. As far as flowering plants are concerned, gene flow is brought about by dispersal of pollen, seeds and vegetative propagules. Reproductive isolation through the prevention of pollen-mediated gene flow is the most important mechanism for the initiation of speciation (Rieseberg \& Willis, 2007). Pollination is the basis of pollen-mediated gene flow involving sexual reproduction. Details of reproductive isolation that operate between populations/species at different stages of sexual reproduction are presented in Table 1.

\section{Modes of speciation}

Allopatric speciation: Evolution of new species in geographically isolated populations as a result of intervention of some physical barrier, such as a rising mountain range or an expanding desert or river that prevents the movement of pollinators between the two populations. Allopatric speciation may also result without the development of new geographic barriers when individuals of a species

Table 1. Various steps in sexual reproduction at which reproductive isolation between populations/ species operate ${ }^{\star}$.

\section{Pre-pollination barriers}

Spatial or temporal isolation: The populations/species flower at different times or separated by geographical barriers/ distance so that the pollinators do not carry pollen across the barrier/distance.

Change in pollinators' preferences as a result of changes in floral traits.

\section{Post-pollination but pre-fertilization barriers}

Pollen grains that land on the stigma are inhibited from germination or pollen tubes from germinated pollen are inhibited in the pistil before reaching the ovule.

\section{Post-fertilization barriers}

Degeneration of hybrid embryo at different stages of development. Even when hybrid embryos are formed, they may not germinate or hybrid plants may not flower or they may be sterile or the few hybrids formed are eliminated because of their poor fitness.

* Reproductive isolation due to pre-pollination barriers is the initial requirement; it is reinforced over time by pre- and post-fertilization barriers as a result of additional mutations, recombination, chromosomal and epigenetic changes. 
colonize a remote area and thus its descendants become geographically isolated from the beginning because of the distance. Physical isolation prevents gene flow between the parental and isolated populations as the pollinators do not move across the barrier or distance. Thus, geographically isolated populations behave as local breeding units; any genotypic or phenotypic changes in them would not enter the original population.

Reproductive isolation initiated through prepollination barriers are gradually reinforced through the development of pre- and postfertilization barriers over a period of time and the isolated population eventually evolves into a new species. Even if the two species subsequently come into secondary contact, they do not form fertile offspring due to genetic incompatibilities, or do not hybridize at all due to the prevalence of pre- and post-fertilization barriers (see Rundle \& Nosil, 2005). Allopatric speciation is faster when isolated populations occupy different environments. Ecological differences may operate in the form of climate, niches, available resources or the presence of predators and competitors (Schluter, 2000). Thus, the newly established populations are subjected to stronger selective pressures and undergo genotypic and phenotypic divergence faster as they adapt to different environmental conditions. Allopatric speciation is considered to be the more common method of speciation when compared to sympatric speciation (Butlin et al., 2008).

Sympatric speciation: This refers to the evolution of a new species within a population through the emergence of reproductive isolation between individuals of the original population. There are two major modes of sympatric speciation pollinator-driven speciation and through polyploidization (see below).

Two other modes of speciation, peripatric (involving divergence of smaller peripheral populations) and parapatric (involving adjoining populations) are included in many books and earlier reviews (Coyne \& Orr, 2004; Lawson et al., 2015). These are now considered as a continuum between sympatric and allopatric speciation (Butlin et al., 2008).

\section{Pollinator-driven speciation}

There is a general agreement amongst evolutionary biologists that insect pollination was the cause of rapid diversification of angiosperms recorded in the Cretaceous period (Magallón \& Castillo, 2009; Smith et al., 2011; Bao et al., 2019). Many floral traits such as flower size and shape, their colour, display, and the quality and quantity of the rewards act as attractants for pollinators. A change in any of these critical floral traits of one or a few individuals within a population may attract a new pollinator instead of the original pollinator thus initiate reproductive isolation. Until recently some evolutionary biologists even doubted the possibility of pollinatordriven sympatric mode of speciation. This was because of the prevalence of the classical view that adaptive mutations generally have very small phenotypic effects and they may not be able to induce reproductive isolation. However, a number of recent studies have shown that a single major mutation may initiate adaptive shift in pollinator preferences (Hoballah et al., 2007; Xu et al., 2012b; Yuan et al., 2013; Fattorini \& Glover, 2020). Thus, species isolation may be achieved by mutation of even just one or a modest number of genes. Pollinator-driven speciation can operate in species which show some degree of floral specialization in attracting a single species of pollinator or one functional group of pollinators such as bees or humming birds or bats, and not easily in generalized pollination systems in which diverse groups of pollinators are effective in transferring pollen (see Fenster et al., 2004; Armbruster \& Muchhala, 2009; Kay \& Sargent, 2009).

Detailed studies in species of Mimulus and Petunia have provided strong evidences for pollinatordriven speciation by documenting specific genes that induce new floral phenotypes leading to a change in pollinator preference (see Yuan et al., 2013). Of these, Mimulus is one of the wellinvestigated systems (Bradshaw et al., 1995; Schemske \& Bradshaw, 1999; Bradshaw \& 
Schemske, 2003). Mimulus has about 120 species showing great variation in floral phenotypes, pollinators and breeding systems. For example, Mimulus lewisii grows only at moderate and higher elevations (1600-3000 m), has pink flowers and small amount of nectar, and bumblebees are the pollinators. Its sister species, $M$. cardinalis grows at lower to high elevations (sea level to $3000 \mathrm{~m}$ ), has red flowers and larger amount of nectar, and humming birds are the pollinators. Although their ranges overlaps at high and moderate elevations in the mountains of California, hybrids are exceedingly rare. The petal colour in these two sister Mimulus species is determined by carotenoid pigments controlled by one quantitative locus, YELLOW UPPER (YUP). The dominant YUP allele in $M$. lewisii prevents carotenoid deposition and the flowers are pink that attracts predominantly bees (Bradshaw \& Schemske, 2003). The recessive yup allele in $M$. cardinalis promotes carotenoid deposition in the petals and the flowers are red. The red flowers do not attract bees effectively but they mostly attract humming birds.

An interesting experiment confirmed the role of petal colour in attracting bees or hummingbirds in these two Mimulus species (Bradshaw \& Schemske, 2003). Near isogenic lines M. cardinalis carrying the dominant YUP allele from $M$. lewisii produced pink flowers. The bees showed strong preference for pink flowers of $M$. cardinalis over red flowered wild type. On the other hand, near isogenic lines of $M$. lewisii carrying recessive $y u p$ allele from $M$. cardinalis produced yellowish-orange flowers; hummingbirds showed strong preference for these flowers. It was the colour of the corolla that changed the pollinator visits and not the shape of the corolla or the amount of nectar in the isogenic lines. Thus, a single trait variation in the flower colour, controlled by one quantitative locus, was enough to initiate a change in pollinator preference and thus to potentially initiate reproductive isolation.

Another example comes from Petunia. Petunia integrifolia has purple scentless flowers with limited nectar and bees are the pollinators whereas $P$. axillaris has white fragrant flowers with considerable amount of nectar and hawkmoths are the pollinators (Hopkins \& Rausher, 2012). The colour difference between $P$. integrifolia and $P$. axillaris was shown to be determined by one gene ANTHOCYANIN2 (AN2) (Quattrocchio et al., 1999; Hoballah et al., 2007) that is involved in anthocyanin biosynthesis. Loss of $A N 2$ function results in white flowers, as is the case in the wild type $P$. axillaries. Transformation of the functional P. integrifolia AN2 allele into P. axillaris background resulted in purple flowers; all other floral characters remained that of the original $P$. axillaris (Hoballah et al., 2007). Interestingly, bumblebees showed a preference for the transformed purple flowers of $P$. axillaris while hawkmoths continued to show a preference to wild type white flowers over purple flowers. Thus one mutation changing the colour of the petal of $P$. axillaris shifted pollinator preference of moths to bees. Subsequent mutations of other traits such as the amount of nectar and scent could stabilized pollinator preferences.

The examples of Mimulus and Petunia described above show pollinator discrimination of the flowers based on visual traits that are controlled by a single gene in each species. There are several other examples of single gene controlled floral traits (Hopkins \& Rausher, 2012; Clegg \& Durbin, 2000; Byers et al., 2014) indicating the role of even a single mutations in initiating reproductive isolation through a change in pollinator preferences in sympatric populations.

\section{Highly specialized species-specific pollination} systems: In a number of species the pollination system is highly specialized in which each plant species is pollinated by just one specific animal species. Although there are quite a few cases of highly specialized pollination systems reported (see Johnson \& Steiner, 2000; Pellmyr, 2002; Galliot et al., 2006; Willmer, 2011; Shivanna, 2014; Kato \& Kawakita, 2017), only two such systems, nursery pollination (figs and fig-wasps) and sexual deception (orchids), are described here in relation to speciation. 
Nursery pollination in figs: There are about 850 species of Ficus and based on our present knowledge, each species of Ficus is considered to be pollinated by a species-specific female fig-wasp species (Wiebes, 1979; Pellmyr, 2002; Weiblen, 2004; Willmer, 2011). Floral scent is a key factor in attracting these species-specific pollinators. The composition of floral scent of each Ficus species reflects species boundaries (Chen et al., 2009; Proffit et al., 2008; Wang et al., 2013). For example, Ficus semicordata is pollinated by the fig-wasp, Ceratosolen gravelyi. One benzenoid compound, 4methylanisole, is the predominant component (9498\%) among the volatile compounds emitted by the receptive fig inflorescences (when they are at the female phase). This compound is entirely absent in the volatiles emitted by fig, four days after pollination, when they no longer attract pollinators. This compound is also absent in the volatiles emitted by two other sympatric fig species, Ficus racemosa and Ficus hispida, both of which are pollinated by other fig-wasp species. Even in laboratory experiments, 4-methylanisole attracts the species-specific pollinator, C. gravelyi. Chemical blends of volatiles lacking this compound do not attract this pollinator. Volatile compounds emitted by receptive figs of the two other sympatric fig species (Ficus racemosa and Ficus hispida) also do not attract the pollinator of $F$. semicordata (Whitehead \& Peakall, 2009).

Sexual deception in orchids: A large number of orchids achieve pollination by sexual deception/mimicry. Their flowers do not offer any rewards but mimic virgin females of the pollinator and also emit a fragrance similar to sex pheromones of virgin females of the pollinator. The male visitor is attracted to the flowers based on olfactory and visual cues, and lands on the flowers. It tries to copulate (termed pseudo-copulation) and brings about pollination during this process by transferring pollinia gathered by previous visits to other flowers (Ayasse et al., 2003; Schiestl et al., 2003; Galizia et al., 2005; Renner, 2006; Xu et al., 2011). Species of Ophrys are well-studied examples on sexual deception. Although several Ophrys species grow sympatrically, each species emits a different fragrance and is pollinated by different species of pollinator. For instance three species of Ophrys, O. lupercalis, O. bilunilata, and O. fabrella, use the same odour compounds for pollinator attraction, but in different proportions (Stökl et al., 2009). This changes the fragrance of each species. Thus, a change of floral odour brought about by the amounts of its components can result in the attraction of a different pollinator in these Ophrys species.

In some deceptive orchids, it has been experimentally shown that male pollinators are attracted even to plastic beads spiked with pheromone attractants and attempt to copulate with them (Peakall et al., 2010; Bohman et al., 2014). Thus, chemical signals alone can mediate attraction of species-specific pollinators. The shape of the flower does not seem to be so important in attracting pollinators; the correct position of the reproductive structures, however, plays a role in effective cross-pollination. Evidence collected so far indicate that changes in floral odour in sexually deceptive orchids are controlled by few genes with large phenotypic effects (see Schiestl et al., 2003; $\mathrm{Xu}$ et al., 2012a,b). A mutation that results in a change in the floral odour is enough to attract a new pollinator that is not attracted by the parental species. This prevents pollen flow to the mutant with changed scent from other individuals of the population. The progeny from the mutant gradually evolves into a new species by reinforcement of other genotypic and phenotypic changes over time.

In fact speciation in sexually deceptive orchids is often based on its pollinator; the populations that do not share the same pollinator have been often considered as different species, independent of their morphological or genetic differences (Stökl et al., 2009; Peakall et al., 2010; Xu et al., 2012a,b). Reproductive isolation in closely related sexually deceptive orchids is largely due to pre-pollination barriers, i.e. differences in pollinator attraction; preand post-fertilization barriers tend to be weak or 
even absent. For example sympatric closely related species of Ophrys, O. exaltata, O. garganica and O. sphegodes attract species-specific solitary bees and do not share their pollinators. However, interspecific hand pollination results in fertile seeds but also fertile hybrids (Xu et al., 2011).

Sustenance of specialized pollination systems during speciation: Plant species with highly specialized species-specific pollination syndromes have many advantages (Pellmyr, 2002; Willmer, 2011; Phillips et al., 2017; Shivanna, 2019). The main advantage being that it increases pollination efficiency as it minimizes pollen loss by preventing pollen wastage to stigmas of other species and also stigma plugging by heterospecific pollen. However, superspecialization also carries many disadvantages. The spread of plant species to new locations is dependent on the availability of their species-specific pollinator, which may often be a major limitation. There is a possibility of pollinators abandoning plant populations when their density goes down below a limit. In nursery pollination systems, both the plant species and their pollinators are dependent on each other for sexual reproduction also; when one of the partners becomes scarce or extinct, the other partner is also prone to eventual extinction. Because of these disadvantages, several investigators since the time of Cope (1896) considered superspecialized pollination systems as 'evolutionary dead ends' prone for extinction (Tripp \& Manos, 2008; Rentsch \& Leebens-Mack, 2014).

The prevailing concept on speciation in highly specialized pollination systems has been that it is the result of co-evolution of the flower and the pollinator. Both the plant species and the pollinator species have undergone simultaneous diversification through joint co-speciation and adaptive radiation (Sanderson \& Donoghue, 1996; Schluter, 2000; Good-Avila et al., 2006); when the plant species splits into two daughter species, its mutualistic pollinator also splits. Several investigations in recent years are not entirely in agreement with this concept of co-speciation of the plant and the pollinator (Molbo et al., 2003; Cruaud et al., 2011;
Vereecken et al., 2012; Shivanna, 2019). It is difficult to expect simultaneous co-speciation of the pollinator that responds to the new odour of the plant species that has diversified from the parent species. It may take many generations of new plant species before its new pollinator evolves and the new mutualism establishes. How would they survive until a new pollinator evolves and establishes?

Highly specialized pollination systems have evolved several flexible strategies, to survive under pollinator constraints (see Shivanna, 2019).

i) Opting out of obligate mutualism by recruiting additional pollinators. A number of studies, mentioned below, have reported that many superspecialized pollination systems are capable of undergoing reversals from specialized to generalized modes. Cruaud et al. (2011) reported one wasp species pollinating at least 50 species of figs and wasp species which are genetically indistinguishable pollinating different host species (see also Molbo et al., 2003; Machado et al., 2005). Similarly in orchids also, there are several reports of gene flow and hybridization amongst sympatric, sexually deceptive species (Danesch et al., 1975; Stökl et al., 2009; Schiestl \& Ayasse, 2002; Schiestl et al., 2003; Cozzolino et al., 2005; Cozzolino \& Scopece, 2008; Gogler et al., 2009).

ii) Evolving an autogamous (self) pollination mode (Catling, 1990; Bond, 1994; Neiland \& Wilcock, 1994, 1995; Johnson \& Steiner, 2000; Peter \& Johnson, 2009). This is highly prevalent in orchids; about $30 \%$ of orchid species investigated are reported to be autogamous (Neiland \& Wilcock, 1994, 1995; Claessens \& Kleynen, 2002).

iii) Rely on or shift to vegetative propagules (e.g. Wang et al., 2004). Further, obligate pollination systems are largely confined to perennials and/or those with the capacity for vegetative propagation (Shivanna, 2019). These adaptations enable them to survive for a number of years/generations until the evolution of new plant - pollinator and eventual stabilization of a new obligate pollination systems. 


\section{Polyploidy}

Whole genome duplication, i.e. autopolyploidy, is common in plants, particularly in vascular plants, when compared to animals, and is an important driver of diversification (Jones, 1970; Stebbins, 1980; Bodt et al., 2005; Wood et al., 2009; Levin, 2002, 2019; Ren et al., 2018; Clark \& Donoghue, 2017; Landis et al.,2018; Cui et al, 2019; Gao, 2019; Qiao et al., 2019; Zhang et al., 2019; Lavania, 2020). The most common pathway of autopolyploid production in the population is through the fusion of unreduced gametes; environmental stresses increase the production of unreduced gametes (see Levin, 2019). Extensive genome-wide studies on genomics in recent years have indicated that all angiosperms have undergone at least one event of polyploidization in their evolutionary history (e.g. Levin, 2002; Jiao et al., 2011; Soltis et al., 2014; Landis et al., 2018; Ren et al., 2018; Qiao et al., 2019). Although a proportion of duplicated genes are retained for long periods, often the genome is reduced in size due to differential loss of genes (genome downsizing) and the chromosome numbers are reduced due to their loss or fusion over time (Leitch \& Bennett, 2004; Storme \& Mason, 2014). Loss of chromosomes in polyploid lines indicates that some of the species even with low chromosome numbers may have derived from polyploid ancestry (see Wood et al., 2009). Polyploidization has contributed to the evolution of novel functions including resistance to diseases and other stresses (see Panchy et al., 2016 and references therein). Polyploids, of both auto- and allopolyploid origins (see below), may disrupt both genetic and epigenomic processes resulting in altered DNA methylation patterns, changes in gene expression and reactivation of transposable elements (Levin, 2002; Alix et al., 2017; Edger et al., 2017; Pelé et al., 2018). Several investigations have shown the role of epigenetic components and transposable elements in enabling organisms to rapidly produce new phenotypes and genotypes in response to stresses (Clegg \& Durbin, 2000; Rey et al., 2016). Polyploidy thus enables new genetic variability upon which natural selection can operate leading to speciation. Many investigators consider the remarkable diversity of angiosperms to be due to the impact of polyploidy (Tank et al., 2015; Pelé et al. 2018; Levin, 2019). Polyploids also show more ecological tolerance and invasiveness when compared to their diploid progenitors (Levin, 2019). Several cultivated species such as Triticum aestivum, Avena sativa, Arachis hypogaea, Nicotiana tabacum, Solanum tuberosum, Coffea arabica and several species of Musa and Brassica have been shown to be polyploids (Hilu, 1993; Wickens, 2001).

Autopolyploidy: Spontaneous autopolyploids (organisms containing more than two complete and identical sets of chromosomes derived from the same species) often occur in populations of diploid species. Polyploids are reproductively isolated in one step. Pollinations between diploids and polyploids result in more or less sterile triploids and do not survive in the population, except where the main reproductive strategy revolves around vegetative propagation (e.g. Curcuma; LeongŠkornicková et al., 2007). Reproductive isolation between parental diploids and polyploids is largely confined to post-fertilization barriers. Polyploids with even chromosome sets (e.g. $4 x, 6 x$, etc.) are fertile, tend to be more vigorous and withstand environmental stresses better than parental diploids; they are likely to increase in the population over time and may eventually replace the diploid plants in the populations (Levin, 2019). Despite the strong and imminent one step reproductive isolation between parental diploid and polyploid 'species', taxonomists may not be able to recognize recent autopolyploids as new species because morphological differences in most of them are too subtle to describe them as new species. Morphological differences have to be reinforced in polyploids through mutations to be able to bring about clear cut phenotypic changes, which may take some time, before taxonomists erect them as new species. This is one of the reasons for the delayed recognition of species resulting from 
autopolyploidy. Autopolyploidy has given rise to many wild as well as cultivated species such as potato and some of its relatives (Grant, 1981) and several species in Saxifragaceae (Soltis \& Rieseberg, 1986; Wolf et al., 1987; Soltis et al., 1989. Many autopolyploid ginger varieties with improved quality have been produced (Smith et al., 2004; Wei et al., 2011).

\section{Hybridization}

Hybridization is another mechanism that drives speciation in plants (e.g. Mallet, 2007; Soltis \& Soltis, 2009). The disruption of physical barriers between previously isolated congeneric species in which reproductive isolation is weak or has not yet evolved fully would allow the formation of hybrids. As pointed out earlier, reproductive isolation even between well recognized sister species is not absolute; some hybrids are produced when the populations of two closely related species come together permitting pollen flow between them. But most of the hybrids may not persist because of sterility and fitness problems but some of them, particularly those with vegetative propagation strategy may persist and evolve into a new species (Leong-Škornicková et al., 2007).

There are two types of hybrid speciation. One is homoploid hybrid speciation in which the hybrids evolve into new species without a change in their chromosome number. The other is allopolyploid hybrid speciation which refers to the origin of new species through duplication of the hybrid genome.

Homoploid hybrid speciation: This mode of speciation is rarer than the allopolyploidy mode; as pointed out earlier, hybrids are generally sterile and also show often reduced fitness, particularly in early generations (but see Yang et al., 2019). However, if they colonize new habitats, particularly those that are not congenial to the parental species, hybrids are likely to show better fitness and successfully establish in new habitats (Campbell \& Waser, 2007). Thus, homoploid hybrids are largely reported in novel habitats that are not occupied by parental species. Several homoploid hybrids have been described (Gross \& Rieseberg, 2005; Soltis \& Soltis, 2009; Yakimowski \& Rieseberg, 2014). Only a few are mentioned here. In Helianthus, $H$. annuus occupies soil that is rich in clay while $H$. petiolarius colonizes sandy soils. It has been shown, based on molecular evidences that three species of Helianthus, each occupying ecological divergent habitats, $-H$. anomalus (sand dune), $H$. deserticola (desert) and $H$. paradoxus (salt marsh), - have evolved through hybridization of $H$. annuus and $H$. petiolaris through homoploid speciation (Rieseberg, 2006; Buerkle \& Rieseberg, 2008). Senecio squalidus derived from $S$. aethnensis $x$ S. chrysanthemifolius is another homoploid hybrid (James \& Abbott, 2005). In the above examples, ecological selection (because of the increased colonization potential of the hybrids) seems to have played a major role in homoploid speciation. Even when the hybrid comes in contact with the parental species that permits pollen flow, the hybrid remains as distinct species; it may not result in the new hybrid progeny because of sterility.

Allopolyploid hybrid speciation: Allopolyploid hybrids are usually fertile when they have an even number of genomes, and genome-wide changes in newly formed allopolyploids induce novel phenotypic and genotypic variations which are likely to contribute to the survival and ultimate success of allopolyploids. Alloploid hybrid speciation is more common than homoploid hybrid speciation and there are a number of examples (Wood et al., 2009; Levin, 2019). Several crops and ornamental species have been shown to be of alloploid origin. Some other reports of allopolyploid species include: Mimulus peregrinus, an allohexaploid (6x) hybrid species between M. guttatus $(2 x)$ and M. luteus (4x) (Vallejo-Marín, 2012). Similarly, Nicotiana tabacum is an allotetraploid hybrid species between $N$. sylvestris $(2 x)$ and $N$. tomentisiformis $(2 x)$ (Sheen, 1972).

As pointed out earlier, speciation in general is a slow process and may take hundreds of generations. However, speciation through polyploids, especially allopolyploids are exceptions in the sense that new 
recognizable species are formed in one or few steps. However, natural selection acts on their sustainability and spread which may take a number of generations during which they undergo many genetic and epigenetic changes in relation to natural selection. Although a large number of hybrid species are formed due to incomplete reproductive isolation of parental species, most of them do not survive and fail to evolve as new species.

\section{Outlook of speciation in the Anthropocene era}

Research and discussions on speciation in flowering plants would, no doubt, continue to be intense in the coming years and the emerging technologies in analytical methods may allow us to study speciation in greater detail. One of the major concerns of human-induced environmental changes including the climate change in recent decades has been its impact on biodiversity. A general consensus amongst conservation biologists has been that as many as one third of species may become extinct by the end of the century which is thousands of times more than the background extinction rate (Barnosky et al., 2011; Ceballos et al., 2020; IUCN, 2020). According to IUCN (2020), 27\% of all assessed species are threatened with extinction. Most of the assessed groups, however, belong to animals. More importantly a large number of species may not become extinct but their population densities and geographical distribution would be reduced to such an extent that they are unable to make any impact on community interactions (see Pimm \& Raven, 2019; Ceballos et al., 2020; Raven, 2020). According to some biologists, plant species seem to be comparatively resistant to extinction when compared to animal species (see Vellend et al., 2017). However, amongst the limited plant groups assessed by IUCN, 34\% of the conifers are reported to be threatened, which is more than many of the threatened animal groups. In a recent detailed study, based on a comprehensive global analysis, Humphreys et al. (2019) documented extinction of about 600 plant species since 1900 (excluding species which were declared extinct but were subsequently rediscovered); this amounts to a 500 times higher than the background extinction rate (see also Ledford, 2019). According to their analysis species on islands and in the tropics particularly those with narrow distribution ranges are more susceptible (Humphreys et al., 2019). The general outlook from the discussions on human-induced mass extinction is that the biodiversity on the planet is going to be markedly reduced in the coming decades.

However, the prevailing biodiversity (both described and un-described) depends on the proportion of the number of species that become extinct to the number of new species formed. In contrast to the availability of enormous literature on species extinction, there is very limited discussion on the impact of climate change on speciation in the coming decades (Thomas, 2015; Bull \& Maron, 2016; Vellend et al., 2017; Otto, 2018; Levin, 2019). A few authors have observed and expected an accelerated rate of speciation in the recent past and coming decades, often referred to as Anthropocene, due to extensive ongoing human-induced environmental and biological changes (Thomas, 2015; Levin, 2019). According to Thomas (2015) the number of new species that have arisen in Europe over the past three centuries are more than the number of species documented as extinct during the same period; this increase has been the result of modern agriculture, horticulture and the human-mediated extensive transport of species across regions, followed by hybridization. According to Levin (2019, but see also Gao, 2019) auto- and allo-polyploidy are going to be the primary modes of speciation in the next 500 years and the proportion of polyploid species would surpass 50\% amongst the described species. He argues that environmental stresses induced due to climate change are likely to trigger higher rates of speciation through mutations and other genetic changes. Equally important, not in relation to speciation but for the sustenance of human welfare, is the responses of crop species to the ongoing climate change (Gornall et al. 2010). Would climate 
change induce higher levels of polyploidy or other genetic changes in crop species in the coming decades leading to the evolution/development of new genotypes/varieties/species so that they are able to sustain productivity and quality of food grains? This is going to be important as it affects food and nutritional security of the increasing population of the world, particularly in developing countries.

\section{Acknowledgements}

I thank Dr M. Sanjappa, Former Director, Botanical Survey of India and Professor M. Sabu, for critically going through the manuscript and making useful suggestions.

\section{Literature Cited}

ABBOTT R.J., RITCHIE M.G. \& P.M. HOLLINGSWORTH 2008. Theme issue introduction. Speciation in plants and animals: pattern and process. Philosophical Transactions of the Royal Society, Series B 363(1506): 2965-2969. https://doi.org/10.1098/ rstb.2008.0096

ALIX K., GÉRARD P.R., SCHWARAZACHER T. \& J.S.(PAT) HESLOP-HARRISON 2017. Polyploidy and interspecific hybridization: partners for adaptation, speciation and evolution in plants. Annals of Botany 120(2): 183-194. https://doi.org/10.1093/aob/mcx079

ARMBRUSTER W.S. \& N. MUCHHALA 2009. Associations between floral specialization and species diversity: cause, effect, or correlation? Evolutionary Ecology 23: 159-179. https://doi.org/10.1007/s10682008-9259-z

ASHBURNER M., CARSON H.L. \& J.N. THOMPSON JR 1981. The genetics and biology of Drosophila. Volume 3a. Academic Press, London.

AYASSE M., SCHIESTL F.P., PAULUS H.F., IBARRA F. \& W. FRANCKE 2003. Pollinator attraction in a sexually deceptive orchid by means of unconventional chemicals. Proceedings of the Royal Society Series B 270 (1514): 517-522. https://doi.org/10.1098/rspb.2002.2271

BALDWIN B.G. \& M.J. SANDERSON 1998. Age and rate of diversification of the Hawaiian silversword alliance (Compositae). Proceedings of the National Academy of Sciences 95(16): 9402-9406. https://doi.org/10.1073/ pnas.95.16.9402

BAO T., WANG B., LI J.G. \& D. DILCHER 2019. Pollination of Cretaceous flowers. Proceedings of the National Academy of Sciences 116(49): 24707-24711. https://doi.org/10.1073/pnas.1916186116
BARNOSKY A.D., MATZKE N., TOMIYA S., WOGEN G.O.U., SWARTZ B., QUENTAL T.B., MARSHALL C., MCGUIRE J.L., LINDSEY E.L., MAGUIRE K.C., MERSEY B. \& E.A. FERRER 2011. Has the earth's sixth mass extinction already arrived? Nature 471: 51-57. https://doi.org/10.1038/nature09678

BODT S. DE, MAERE S. \& Y. VAN DE PEER 2005. Genome duplication and the origin of angiosperms. Trends in Ecology and Evolution 20(11): 591-597. https:/ /doi.org/10.1016/j.tree.2005.07.008

BOHMAN B., PHILLIPS R.D., MENZ M.H.M., BERNTSSON B.W., FLEMATTI G.R., BARROW R.A., DIXON K.W. \& R. PEAKALL 2014. Discovery of pyrazines as pollinator sex pheromones and orchid semiochemicals: implications for the evolution of sexual deception. New Phytologist 203: 939-952. https:// doi.org/10.1111/nph.12800

BOND W.J. 1994. Do mutualisms matter? Assessing the impact of pollinator and disperser disruption on plant extinction. Philosophical Transactions of the Royal Society Series B 344 (1307): 83-90. https://doi.org/10.1098/ rstb.1994.0055

BRADSHAW H.D. JR \& D.W. SCHEMSKE 2003. Allele substitution at a flower colour locus produces a pollinator shift in monkey flowers. Nature 426: 176-178. https:// doi.org/10.1038/nature02106

BRADSHAW H.D. JR, WILBERT S.M., OTTO K.G. \& D.W. SCHEMSKE 1995. Genetic mapping of floral traits associated with reproductive isolation in monkey flowers (Mimulus). Nature 376: 762-765. https://doi.org/ 10.1038/376762a0

BUERKLE C.A. \& L.H. RIESEBERG 2008. The rate of genome stabilization in homoploid hybrid species. Evolution 62(2): 266-275. https://doi.org/10.1111/ j.1558-5646.2007.00267.x

BULL J.W. \& M. MARON 2016. How humans drive speciation as well as extinction. Proceedings of the Royal Society Series B 283(1833): 20160600. https://doi.org/ 10.1098/rspb.2016.0600

BUTLIN R.K., GALINDO J. \& J.W. GRAHAME 2008. Sympatric, parapatric or allopatric: the most important way to classify speciation? Philosophical Transactions of the Royal Society Series B 363(1506): 2997-3007. https:/ /doi.org/10.1098/rstb.2008.0076

BYERS K.J.R.P., VELA J.P., PENG F., RIFFELL J.A. \& H.D. BRADSHAW JR 2014. Floral volatile alleles can contribute to pollinator-mediated reproductive isolation in monkey flowers (Mimulus). Plant Journal 80(6): 10311042. https://doi.org/10.1111/tpj.12702

CAMPBELL D.R. \& N.M. WASER 2007. Evolutionary dynamics of an Ipomopsis hybrid zone: confronting models with lifetime fitness data. American Naturalist 169(3): 298-310. https://doi.org/10.1086/510758 
CATLING P.M. 1990. Auto-pollination in the Orchidaceae. In: ARDITTI V.J. (ed.), Orchid Biology: Reviews and Perspectives. Timber Press, Portland. pp. 121-158.

CEBAllos G., EHRLICH P.R. \& P.H. RAVEN 2020. Vertebrates on the brink as indicators of biological annihilation and the sixth mass extinction. Proceedings of the National Academy of Sciences 117(24): 1359613602. https://doi.org/10.1073/pnas.1922686117

CHEN C., SONG Q.S., PROFFIT M., BESSIÈRE J.M., LI Z.B. \& M. HOSSAERT-MCKEY 2009. Private channel: a single unusual compound assures specific pollinator attraction in Ficus semicordata. Functional Ecology 23(5): 941-950. https://doi.org/10.1111/j.13652435.2009.01622.x

CLAESSENS J. \& J. KLEYNEN 2002. Investigations on the autogamy in Ophrys apifera Hudson. Jahresberichte des Naturwissenschaftlichen Vereins Wuppertal 55: 62-77.

CLARK, J.W. \& P.C.J. DONOGHUE 2017. Constraining the timing of whole genome duplication in plant evolutionary history. Proceedings of the Royal Society Series B 284(1858): 20170912. http://dx.doi.org/10.1098/ rspb.2017.0912

CLEGG, M.T. \& M.L. DURBIN 2000. Flower color variation: a model for the experimental study of evolution. Proceedings of the National Academy of Sciences 97(13): 7016-7023. https://doi.org/10.1073/pnas.97.13.7016

COIRO M, DOYLE J.A. \& J. HILTON 2019. Tansley review. How deep is the conûict between molecular and fossil evidence on the age of angiosperms? New Phytologist 223: 83-99. https://doi.org/10.1111/ nph.15708

COPE E.D. 1896. The primary factors of organic evolution. Open Court Publishing, Chicago.

COYNE J.A. \& H.A. ORR 2004. Speciation. Sinauer Associates, Sunderland, Massachusetts.

COZZOLINO S. \& G. SCOPECE 2008. Specificity in pollination and consequences for postmating reproductive isolation in deceptive Mediterranean orchids. Philosophical Transactions of the Royal Society Series B 363(1506): 33037-3046. https://doi.org/ 10.1098/rstb.2008.0079

COZZOLINO S., SCHIESTL F.P., MÜLLER A., DE CASTRO O., NARDELLA A.M. \& A. WIDMER 2005. Evidence for pollinator sharing in Mediterranean nectarmimic orchids: absence of premating barriers? Proceedings of the Royal Society Series B 272 (1569): 12711278. https://doi.org/10.1098/rspb.2005.3069

CRANE P.E., M.F. FRIIS \& K.R. PEDERSEN 2000. The origin and early diversification of angiosperms. In: GEE H. (ed.), Shaking the tree: Readings from Nature in the History of Life. University of Chicago Press, Illinois. pp. 233-250.
CREPET W.L. \& K.J. NIKLAS 2009. Darwin's second "abominable mystery": why are there so many angiosperm species? American Journal of Botany 96(1): 366-381. https://doi.org/10.3732/ajb.0800126

CRUAUD A., COOK J., YANG D.R., GENSON G., JABBOUR-ZAHAB R., KJELLBERG F., PEREIRA R.A.S., RØNSTED N., SANTOS-MATTOS O., SAVOLAINEN V., UBAIDILLAH R., VAN NOORT S., PENG Y.Q. \& J.Y. RASPLUS 2011. Fig-fig wasp mutualism: the fall of the strict cospeciation paradigm? In: PATINY S. (ed.), Evolution of plant-pollinator relationships. Systematic Association Special Volume 81. Cambridge University Press, Cambridge. pp. 68-102.

CUI L.Y., WALL P.K., LEEBENS-MACK J.H., LINDSAY B.G., SOLTIS D.E., DOYLE J.J., SOLTIS P.S., CARLSON J.E., ARUMUGANATHAN K., BARAKAT A., ALBERT V.A., MA H. \& C.W. DE PAMPHILIS 2019. Widespread genome duplications throughout the history of flowering plants. Genome Research 16: 738-749. https://doi.org/10.1101/ gr.4825606

DANESCH O., DANESCH E., EHRENDORFER F. \& K. EHRENDORFER 1975. Hybrids and hybrid taxa from Ophrys bertolonii and Ophrys atrata (Orchidaceae). Plant Systematic and Evolution 124: 79-123.

DARWIN C. 1859. On the Origin of Species by Means of Natural Selection. Murray, London.

DOBZHANSKY T. 1937. Genetics and the Origin of Species. Columbia University Press, New York.

EDGER P.P., SMITH R., MCKAIN M.R., COOLEY A.M., VALLEJO-MARÍN M., YUAN Y.W., BEWICK A.J., JI L.X., PLATTS A.E., BOWMAN M.J., CHILDS K.L., WASHBURN J.D., SCHMITZ R.J., SMITH G.D., PIRES J.C. \& J.R. PUZEY 2017. Subgenome dominance in an interspecific hybrid, synthetic allopolyploid, and a 140-year-old naturally established neo-allopolyploid monkeyflower. Plant Cell 29: 2150 2167. https://doi.org/10.1105/tpc.17.00010

ELDREDGE N. \& J. CRACRAFT 1980. Phylogenetic patterns and the evolutionary process: Method and theory in comparative biology. Columbia University Press, New York.

FATTORINI R. \& B.J. GLOVER 2020. Molecular mechanisms of pollination biology. Annual Review of Plant Biology 71: 487-515. https://doi.org/10.1146/ annurev-arplant-081519-040003

FENSTER C.B., ARMBRUSTER W.S., WILSON P., DUDASH M.R. \& J.D. THOMSON 2004. Pollination syndrome and floral specialization Annual Review of Ecology, Evolution and Systematics 35: 375-403. https:// doi.org/10.1146/annurev.ecolsys.34.011802.132347 
FERGUSON D. \& T. SANG 2001. Speciation through homoploid hybridization between allotetraploids in peonies (Paeonia). Proceedings of the National Academy of Sciences 98(7): 3915-3919. https://doi.org/10.1073/ pnas.061288698

FERRER M.M. \& S.V. GOOD 2012. Self-sterility in flowering plants: preventing self-fertilization increases family diversification rates. Annals of Botany 110(3): 535553. https://doi.org/10.1093/aob/mcs124

GALIZIA, C.G., KUNZE J., GUMBERT A., BORGKARLSON A.K., SACHSE S., MARKL C. \& R. MENZEL 2005. Relationship of visual and olfactory signal parameters in a food-deceptive flower mimicry system. Behavioral Ecology 16(1): 159-168. https:// doi.org/10.1093/beheco/arh147

GALLIOT C., STUURMAN J. \& C. KUHLEMEIER 2006. The genetic dissection of floral pollination syndromes. Current Opinion in Plant Biology 9(1): 78-82. https:// doi.org/10.1016/j.pbi.2005.11.003

GAO J.G. 2019. Dominant plant speciation types. A commentary on: plant speciation in the age of climate change. Annals of Botany 124(5): iv-vi. https://doi.org/ 10.1093/aob/mcz174

GOGLER J., STÖKL J., SRAMKOVA A., TWELE R., FRANCKE W., COZZOLINO S., CORTIS P., SCRUGLI A. \& M. AYASSE 2009. Ménage à trois two endemic species of deceptive orchids and one pollinator species. Evolution 63: 2222-2234. https:// doi.org/10.1111/j.1558-5646.2009.00712.x

GOOD-AVILA S.V., SOUZA V., GAUT B.S. \& L.E. EGUIARTE 2006. Timing and rate of speciation in Agave (Agavaceae). Proceedings of the National Academy of Sciences 103(24): 9124-9129. https://doi.org/10.1073/ pnas.0603312103

GORNALL J., BETTS R., BURKE E., CLARK R., CAMP J., WILLETT K. \& A. WILTSHIRE 2010. Implications of climate change for agricultural productivity in the early twenty-first century. Philosophical Transactions of the Royal Society Series B 365(1554): 2973-2989. https:/ /doi.org/10.1098/rstb.2010.0158

GRANT V. 1981. Plant Speciation. Columbia University Press. New York.

GROSS B.L. \& L.H. RIESEBERG 2005. The ecological genetics of homoploid hybrid speciation. Journal of Heredity 96(3): 241-252. https://doi.org/10.1093/jhered/ esi026

HEY J., FITCH W.M. \& J. AYALA 2005. Systematics and the origin of species: an introduction. Proceedings of the National Academy of Sciences 102(Suppl.1): 6515-6519. https://doi.org/10.1073/pnas.0501939102
HILU K.W. 1993. Polyploidy and the evolution of domesticated plants. American Journal of Botany 80: 14941499. https://doi.org/10.1002/j.1537-2197.1993.tb15395.x

HOBALLAH M.E., GÜBITZ T., STUURMAN J., BROGER L., BARONE M., MANDEL T., DELL'OLIVO A., ARNOLD M. \& C. KUHLEMEIER 2007. Single gene-mediated shift in pollinator attraction in Petunia. Plant Cell 19: 779-790. https://doi.org/ 10.1105/tpc.106.048694

HOFFMAN A.A. \& J. MERILÄ 1999. Heritable variation and evolution under favourable and unfavourable conditions. Trends Ecology and Evolution 14: 96-101. https://doi.org/10.1016/s0169-5347(99)01595-5

HOPKINS R. \& M.D. RAUSHER 2012. Pollinatormediated selection on flower color allele drives reinforcement. Science 335(6072): 1090-1092. https:// doi.org/10.1126/science.1215198

HUMPHREYS A.M., GOVAERTS R., FICINSKI S.Z., LUGHADHA E.N. \& M.S. VORONTSOVA 2019. Global dataset shows geography and life form predict modern plant extinction and rediscovery. Nature Ecology E Evolution 3: 1043-1047. https://doi.org/10.1038/ s41559-019-0906-2

IUCN 2020. The IUCN Red List of threatened species. Version 2020-1. Available at: https://www.iucnredlist.org (Accessed on 19.03.2020).

JAMES J.K. \& R.J. ABBOTT 2005. Recent, allopatric, homoploid hybrid speciation: the origin of Senecio squalidus (Asteraceae) in the British Isles from a hybrid zone on Mount Etna, Sicily. Evolution 59(12): 25332547. https://www.jstor.org/stable/3449048

JANSSENS S.B., COUVREUR T.L.P., MERTENS A., DAUBY G., DAGALLIER L.P.M.J., VANDEN ABEELE S., VANDELOOK F., MASCARELLO M., BEECKMAN H., SOSEF M., DROISSART V., VAN DER BANK M., MAURIN O., HAWTHORNE W., MARSHALL C., RÉJOU-MÉCHAIN M., BEINA D., BAYA F., MERCKX V., VERSTRAETE B. \& O. HARDY 2020. A large-scale species level dated angiosperm phylogeny for evolutionary and ecological analyses. Biodiversity Data Journal 8: e39677. https:// doi.org/10.3897/BDJ.8.e39677

JIAO Y., WICKETT N.J., AYYAMPALAYAM S., CHANDERBALI A.S., LANDHERR L., RALPH P.E., TOMSHO L.P., HU Y., LIANG H.Y., SOLTIS P.S., SOLTIS D.E., CLIFTON S.W., SCHLARBAUM S.E., SCHUSTER S.C., MA H., LEEBENS-MACK J. \& C.W. DE PAMPHILIS 2011. Ancestral polyploidy in seed plants and angiosperms. Nature 473: 97-100. https:/ /doi.org/10.1038/nature09916

JOHNSON S.D. \& K.E. STEINER 2000. Generalization versus specialization in plant pollination systems. Trends 
in Ecology and Evolution 15(4): 140-143. https:/doi.org/ 10.1016/s0169-5347(99)01811-x

JONES K. 1970. Chromosome changes: reliable indicators of the direction of evolution? Taxon 19: 172-179.

KATO M. \& A. KAWAKITA 2017. Obligate pollination mutualism. Ecological Research Monographs, Springer, Tokyo.

KAY K.M. \& R.D. SARGENT 2009. The role of animal pollination in plant speciation: integrating ecology, geography, and genetics. Annual Review of Ecology, Evolution \& Systematics 40: 637-656. https://doi.org/ 10.1146/annurev.ecolsys.110308.120310

LANDIS G.B., SOLTIS D.E., LI Z, MARX H.E., BARKER M.S., TANK D.C. \& P.S. SOLTIS 2018. Impact of whole genome duplication events on diversification rates in angiosperms. American Journal of Botany 105(3): 348363. https://doi.org/10.1002/ajb2.1060

LAPORT, R.G. \& J. NG 2017. Out of one, many: the biodiversity considerations of polyploidy. American Journal of Botany 104(8): 1119-1121. https://doi.org/ 10.3732/ajb.1700190

LAVANIA U.C. 2020. Plant speciation and polyploidy: in habitat divergence and environmental perspectives. The Nucleus 63: 1-5. https://doi.org/10.1007/s13237-02000311-6

LAWSON L.P., BATES J.M., MENEGON M. \& S.P. LOADER 2015. Divergence at the edges: peripatric isolation in the montane spiny throated reed frog complex. BMC Evolutionary Biology 15: 128. https:// doi.org/10.1186/s12862-015-0384-3

LAZCANO A. \& S.L. MILLER 1996. The origin and early evolution of life: prebiotic chemistry, the pre-RNA world, and time. Cell 85: 793-798. https://doi.org/ 10.1016/S0092-8674(00)81263-5

LEDFORD H. 2019. World's largest survey reveals alarming extinction rate. Nature 570: https://doi.org/10.1038/ d41586-019-01810-6

LEITCH I.J. \& M.D. BENNETT 2004. Genome downsizing in polyploid plants. Biological Journal of the Linnean Society 82(4): 651-663. http://doi.org/10.1111/ j.1095-8312.2004.00349.x

LEONG-ŠKORNIÈKOVÁ J., ŠÍDA O., JAROLÍMOVÁ V., SABU M., FÉR T., TRÁVNÍEK P. \& J. SUDA 2007. Chromosome numbers and genome size variation in Indian species of Curcuma (Zingiberaceae). Annals of Botany 100(3): 505-526. https://doi.org/10.1093/aob/ mcm144

LEVIN D.A. 2002. The role of chromosomal change in plant evolution. Oxford University Press, New York.

LEVIN D.A. 2019. Plant speciation in the age of climate change. Annals of Botany 124(5): 769-775. https:// doi.org/10.1093/aob/mcz108

LEXER C. \& A. WIDMER 2008. The genic view of plant speciation: recent progress and emerging questions. Philosophical Transactions of the Royal Society Series B 363(1506): 3023-3036. https://doi.org/10.1098/ rstb. 2008.0078

LI H-T., YI T.S., GAO L.M., MA P.F., ZHANG T., YANG J.B., GITZENDANNER M.A., FRITSCH P.W., CAI J., LUO Y., WANG H., VAN DER BANK M., ZHANG S.D., WANG Q.F., WANG J., ZHANG Z.R., FU C.N., YANG J., HOLLINGSWORTH P.M., CHASE M.W., SOLTIS D.E., SOLTIS P.S. \& D.Z. LI 2019. Origin of angiosperms and the puzzle of the Jurassic gap. Nature Plants 5: 461-470. https://oi.org/ 10.1038/s41477-019-0421-0

MACHADO C.A., ROBBINS N., GILBERT M.T.P. \& E.A. HERRE 2005. Critical review of host specificity and its coevolutionary implications in the fig/fig-wasp mutualism. Proceedings of the National Academy of Sciences 102(suppl. 1): 6558-6565. https://doi.org/10.1073/ pnas.0501840102

MAGAllÓN, S. \& A. CASTILlO 2009. Angiosperm diversification through time. American Journal of Botany 96(1): 349-365. https://doi.org/10.3732/ajb.0800060

MALLET J. 2007. Hybrid speciation. Nature 446: 279-283. https://doi.org/10.1038/nature05706

MAYR E. 1942. Systematics and the origin of species. Columbia University Press, New York.

MOLBO D., MACHADO C.A., SEVENSTER J.G., KELLER L. \& E.A. HERRE 2003. Cryptic species of fig-pollinating wasps: implications for the evolution of the fig-wasp mutualism, sex allocation, and precision of adaptation. Proceedings of the National Academy of Sciences 100(10): 5867-5872. https://doi.org/10.1073/ pnas.0930903100

MORA C., TITTENSOR D.P., ADL S., SIMPSON A.G.B. $\&$ B. WORM 2011. How many species are there on earth and in the ocean? PLoS Biology 9(8), e1001127. https://doi.org/10.1371/journal.pbio.1001127

NEILAND, M.R.M. \& C.C. WILCOCK 1994. Reproductive ecology of European Orchidaceae. In: PRIDGEON A.M. (ed.), Proceedings of the Fourteenth World Orchid Conference. HMSO, Edinburgh. pp. 138-147.

NEILAND, M.R.M. \& C.C. WILCOCK 1995. Maximization of reproductive success by European Orchidaceae under conditions of infrequent pollination. Protoplasma 187: 39-48. https://doi.org/10.1007/ BF01280231 
OLSEN S. 2004. Evolution in Hawaii: a supplement to teaching about evolution and the nature of science. The National Academies Press, Washington D.C.

OTTO S.P. 2018. Adaptation, speciation and extinction in the Anthropocene. Proceedings of the Royal Society Series B 285(1891): 20182047. https://doi.org/10.1098/ rspb.2018.2047

PANCHY N., LEHTI-SHIU M. \& S.H. SHIU 2016. Evolution of gene duplication in plants. Plant Physiology 171: 2294-2316. https://doi.org/10.1104/pp.16.00523

PATEL, B.H., PERCIVALLE, C., RITSON, D.J., DUFFY C.D. \& J.D. SUTHERLAND 2015. Common origins of RNA, protein and lipid precursors in a cyanosulfidic protometabolism. Nature Chemistry 7: 301-307. https:/ /doi.org/10.1038/nchem.2202

PEAKALL R., EBERT D., POLDY J., BARROW R.A., FRANCKE W., BOWER C.C. \& F.P. SCHIESTL 2010. Pollinator specificity, floral odour chemistry and the phylogeny of Australian sexually deceptive Chiloglottis orchids: implications for pollinator-driven speciation. New Phytologist 188(2): 437-450. https:// doi.org/10.1111/j.1469-8137.2010.03308.x

PELÉ A., ROUSSEAU-GUEUTIN M. \& A.M. CHÈVRE 2018. Speciation success of polyploid plants closely relates to the regulation of meiotic recombination. Frontiers in Plant Science. https://doi.org/10.3389/ fpls.2018.00907

PELLMYR O. 2002. Pollination by animals. In: HERRERA C.M. \& O. PELLMYR (eds.), Plant-animal interaction. An evolutionary approach. Wiley-Blackwell Publishing, Oxford. pp. 157-184.

PETER, C.I. \& S.D. JOHNSON 2009. Autonomous selfpollination and pseudo-fruit set in South African species of Eulophia (Orchidaceae). South African Journal of Botany 75(4): 791-797. https://doi.org/10.1016/ j.sajb.2009.07.007

PETREN K., GRANT P.R., GRANT B.R. \& L.F. KELLER 2005. Comparative landscape genetics and the adaptive radiation of Darwin's finches: the role of peripheral isolation. Molecular Ecology 14(10): 2943-2957. https:// doi.org/10.1111/j.1365-294X.2005.02632.x

PHILLIPS R.D., BROWN G.R., DIXON K.W., HAYES C., LINDE C.C. \& R. PEAKALL 2017. Evolutionary relationships among pollinators and repeated pollinator sharing in sexually deceptive orchids. Journal of Evolutionary Biology 30(9): 1674-1691. https://doi.org/ 10.1111/jeb.13125

PIMM, S. L. \& P.H. RAVEN 2019. The state of the world's biodiversity. In: DASGUPTA, P., RAVEN P.H. \& A. MCIVOR (eds.), Biological extinction: new perspectives. Cambridge University Press, Cambridge. pp. 80-112.
PROFFIT, M., SCHATZ B., BESSIERE J.M., CHEN C., SOLER C. \& M. HOSSAERT-MCKEY 2008. Signaling receptivity: comparison of the emission of volatile compounds by figs of Ficus hispida before, during and after the phase of receptivity to pollinators. Symbiosis 45: 15-24.

QIAO X., LI Q.H., YIN H., QI K.J., LI L.T., WANG R., ZHANG S.L. \& A.H. PATERSON 2019. Gene duplication and evolution in recurring polyploidizationdiploidization cycles in plants. Genome Biology 20: 38. https://doi.org/10.1186/s13059-019-1650-2

QUATTROCCHIO F., WING J., VAN DER WOUDE K., SOUER E., DE VETTEN N., MOL J. \& R. KOES 1999. Molecular analysis of the anthocyanin2 gene of Petunia and its role in the evolution of flower color. Plant Cell 11: 1433-1444. https://doi.org/10.1105/tpc.11.8.1433

QUEIROZ K. DE 2007. Species concepts and species delimitation. Systematic Biology 56 (6): 879-886. https:/ /doi.org/10.1080/10635150701701083

RAVEN P.H. 2020. Biological extinction and climate change. In: AL-DELAIMY W.K., RAMANATHAN V. \& M. SÁNCHEZ SORONDO (eds.), Health of people, health of planet and our responsibility. Springer International Publishing, Switzerland. pp. 11-20. https:/ /doi.org/10.1007/978-3-030-31125-4_2

REN R., WANG H.F., GUO C.C., ZHANG N., ZENG L.P., CHEN Y.M., MA H. \& J. QI 2018. Widespread whole genome duplications contribute to genome complexity and species diversity in angiosperms. Molecular Plant 11(3): 414-428. https://doi.org/10.1016/ j.molp.2018.01.002

RENNER S.S. 2006. Rewardless flowers in the angiosperms and the role of insect cognition in their evolution. In: WASER, N.W. \& J. OLLERTON (eds.), Plantpollinator interactions: from specialization to generalization. University of Chicago Press, Chicago. pp. 123-144.

RENTSCH, J.D. \& J. LEEBENS-MACK 2014. Yucca aloifolia (Asparagaceae) opts out of an obligate pollination mutualism. American Journal of Botany 101(12): 2062-2067. https://doi.org/10.3732/ ajb.1400351

REY O., DANCHIN E., MIROUZE M., LOOT C. \& S. BLANCHET 2016. Adaptation to global change: a transposable element-epigenetics perspective. Trends in Ecology and Evolution 31(7): 514-526. https://doi.org/ 10.1016/j.tree.2016.03.013

RIESEBERG L.H. 2006. Hybrid speciation in wild sunflowers. Annals of Missouri Botanical Garden 93(1): 34-48. https://www.jstor.org/stable/40035044

RIESEBERG L.H. \& J.H. WILLIS 2007. Plant speciation. Science 317(5840): 910-914. https://doi.org/10.1126/ science. 1137729 
RUNDLE H.D. \& P. NOSIL 2005. Ecological speciation. Ecology Letters 8(3): 336-352. https://doi.org/10.1111/ j.1461-0248.2004.00715.x

SANDERSON M.J. \& M.J. DONOGHUE 1996. Reconstructing shifts in diversification rates on phylogenetic trees. Trends in Ecology and Evolution 11(1): 15-20. https://doi.org/10.1016/0169-5347(96)81059-7

SCHEMSKE D.W. \& H.D. BRADSHAW JR 1999. Pollinator preference and the evolution of floral traits in monkey flowers (Mimulus). Proceedings of the National Academy of Sciences 96(21): 11910-11915. https:// doi.org/10.1073/pnas.96.21.11910

SCHIESTL F.P. \& M. AYASSE 2002. Do changes in floral odor cause speciation in sexually deceptive orchids? Plant Systematics and Evolution 234(1/4): 111-119. https:// doi.org/10.1007/s00606-002-0187-z

SCHIESTL F.P., PEAKALL R., MANT J.G., IBARRA F. SCHULZ C., FRANKE S. \& W. FRANCKE 2003. The chemistry of sexual deception in an orchid-wasp pollination system. Science 302(5644): 437-438. https:// doi.org/10.1126/science.1087835

SCHLUTER D. 2000. The ecology of adaptive radiation. Oxford University Press, Oxford.

SHEEN S.J. 1972. Isozymic evidence bearing on the origin of Nicotiana tabacum L. Evolution 26(1): 143-154. https:/ /doi.org/10.1111/j.1558-5646.1972.tb00181.x

SHIVANNA, K.R. 2014. Biotic pollination: how do plants achieve conflicting demands of attraction and restriction of potential pollinators. In: RAMAWAT, K.G., MERILLON J.M. \& K.R. SHIVANNA (eds.), Reproductive Biology of Plants. CRC Press, Boca Raton. pp. 218-267.

SHIVANNA K.R. 2019. Have highly specialized pollination systems reached an evolutionary dead end? Phytomorphology 69: 1-14.

SIMPSON G.G. 1951. The species concept. Evolution 5(4): 285-298. https://doi.org/10.2307/2405675

SMITH M.K., HAMILL S.D., GOGEL B.J. \& A.A. SEVERN-ELLIS 2004. Ginger (Zingiber officinale) autotetraploids with improved processing quality produced by an in vitro colchicine treatment. Australian Journal of Experimental Agriculture 44: 1065-1072. https:/ /doi.org/10.1071/EA03204

SMITH S.A., BEAULIEU J.M., STAMATAKIS A. \& M.J. DONOGHUE 2011. Understanding angiosperm diversification using small and large phylogenetic trees. American Journal of Botany 98(3): 404-414. https:// doi.org/10.3732/ajb.1000481

SOBEL J.M., CHEN G.F., WATT L.R. \& D.W. SCHEMSKE 2010. The biology of speciation. Evolution 64(2): 295-315. https://doi.org/10.1111/j.15585646.2009.00877.x
SOLTIS D.E. \& L.H. RIESEBERG 1986. Autopolyploidy in Tolmiea menziesii (Saxifragaceae): genetic insights from enzyme electrophoresis. American Journal of Botany 73(2): 310-318. https://doi.org/10.1002/j.15372197.1986.tb08534.x

SOLTIS P.S. \& D.E. SOLTIS 2009. The role of hybridization in plant speciation. Annual Review of Plant Biology 60: 561-588. https://doi.org/10.1146/ annurev.arplant.043008.092039

SOLTIS D.E., SOLTIS P.S., RANKER T.A. \& B.D. NESS 1989. Chloroplast-DNA variation and multiple origins of autopolyploidy in Heuchera micrantha (Saxifragaceae). Evolution 43: 650-656.

SOLTIS D.E., VISGER C.J. \& P.S. SOLTIS 2014. The polyploidy revolution then... and now: Stebbins revisited. American Journal of Botany 101(7): 1057-1078. https://doi.org/10.3732/ajb.1400178

STEBBINS G.L. 1950. Variation and Evolution in Plants. Columbia University Press, New York.

STEBBINS G.L. 1980. Polyploidy in plants: unresolved problems and prospects. In: LEWIS W.H. (ed.), Polyploidy. Plenum Press, New York. pp. 495-520.

STÖKL J., SCHLÜTER P.M., STUESSY T.F., PAULUS H.F., FRABERGER R., ERDMANN D., SCHULZ C., FRANCKE W., ASSUM G. \& M. AYASSE 2009. Speciation in sexually deceptive orchids: pollinatordriven selection maintains discrete odour phenotypes in hybridizing species. Botanical Journal of the Linnaean Society 98(2): 439-451. https://doi.org/10.1111/j.10958312.2009.01279.x

STORME N. DE \& A. MASON 2014. Plant speciation through chromosome instability and ploidy change: cellular mechanisms, molecular factors and evolutionary relevance. Current Plant Biology 1:10-33. https://doi.org/ 10.1016/j.cpb.2014.09.002

TANK D.C., EASTMANJ.M., PENNELL M.W., SOLTIS P.S., SOLTIS D.E., HINCHLIFF C.E., BROWN J.W., SESSA E.B. \& L.J. HARMON 2015. Nested radiations and the pulse of angiosperm diversification: increased diversification rates often follow whole genome duplications. New Phytologist 207(2): 454-467. https:// doi.org/10.1111/nph.13491

THOMAS C.D. 2015. Rapid acceleration of plant speciation during the Anthropocene. Trends in Ecology and Evolution 30(8): 448-455. https://doi.org/10.1016/ j.tree.2015.05.009

TRIPP E.A. \& P.S. MANOS 2008. Is floral specialization an evolutionary dead-end? Pollination system transitions in Ruellia (Acanthaceae). Evolution 62(7): 1712-1737. https://doi.org/10.1111/j.1558-5646.2008.00398.x 
TSAFTARIS A.S. \& A.N. POLIDOROS 2000. DNA methylation and plant breeding. Plant Breeding Reviews 18: 87-176. https://doi.org/10.1002/9780470650158.ch3

VALLEJO-MARÍN M. 2012. Mimulus peregrinus (Phrymaceae): a new British allopolyploid species. PhytoKeys 14: 1-14. https://doi.org/10.3897/ phytokeys.14.3305

VAN DER KOOI C.J. \& J. OLLERTON 2020. The origins of flowering plants and pollinators. Science 368 (6497): 1306-1308. https://doi.org/10.1126/science.aay3662

VAN DER NIET T., PEAKALL R. \& S.D. JOHNSON 2014. Pollinator-driven ecological speciation in plants: new evidence and future perspectives. Annals of Botany 113(2): 199-212. https://doi.org/10.1093/aob/mct290

VELLEND M., BAETEN L., BECKER-SCARPITTA A., BOUCHER-LALONDE V., MCCUNE J.L., MESSIER J., MYERS-SMITH I.H. \& D.F. SAX 2017. Plant biodiversity change across scales during the Anthropocene. Annual Review of Plant Biology 68: 563586. https://doi.org/10.1146/annurev-arplant-042916040949

VEREECKEN N.J., WILSON C.A., HÖTLING S., SCHULZ S., BANKETOV S.A. \& P. MARDULYN 2012. Pre-adaptations and the evolution of pollination by sexual deception: Cope's rule of specialization revisited. Proceedings of the Royal Society Series B 279(1748): 4786-4794. https://doi.org/10.1098/ rspb.2012.1804

WANG G., COMPTON S.G. \& J. CHEN 2013. The mechanism of pollinator specificity between two sympatric fig varieties: a combination of olfactory signals and contact cues. Annals of Botany 111(2): 173-181. https://doi.org/10.1093/aob/mcs250

WANG C.N., MÖLLER M. \& Q.C.B. CRONK 2004. Aspects of sexual failure in the reproductive processes of a rare bulbiliferous plant, Titanotrichum oldhamii (Gesneriaceae) in subtropical Asia. Sexual Plant Reproduction 17: 23-31. https://doi.org/10.1007/s00497004-0213-0

WEI K.H., MIAO J.H., HUANG H.P. \& S.L. GAO 2011. Generation of autotetraploid plant of ginger (Zingiber officinale Rosc.) and its quality evaluation. Pharmacognosy Magazine 7(27): 200-206. https://doi.org/10.4103/09731296.84230

WEIBLEN G.D. 2004. Correlated evolution in fig pollination. Systematic Biology 53(1): 128-139. https:// doi.org/10.1080/10635150490265012

WHITEHEAD M.R. \& R. PEAKALL 2009. Integrating floral scent, pollination ecology and population genetics. Functional Ecology 23(5): 863-874. https://doi.org/ 10.1111/j.1365-2435.2009.01620.x

WICKENS G.E. 2001. Economic Botany: Principles and Practices, Kluwer Academic Publishers, Dordrecht.
WIEBES J.T. 1979. Coevolution of figs and their insect pollinators. Annual Review of Ecology and Systematics 10: 1-12. https://doi.org/10.1146/annurev.es.10.110179. 000245

WILEY E.O. 1978. The evolutionary species concept reconsidered. Systematic Zoology 27(1): 17-26. https:// doi.org/10.2307/2412809

WILLMER P. 2011. Pollination and Floral Ecology. Princeton University Press, Princeton, Oxford.

WOLF P.G., SOLTIS P.S. \& D.E. SOLTIS 1987. Autopolyploidy evolution in Heuchera grassularifolia (Saxifragaceae) (Abstract of paper presented at the annual meeting of the American Institute of Biological Sciences). American Journal of Botany 74: 767.

WOOD T.E., TAKEBAYASHI N., BARKER M.S., MAYROSE I., GREENSPOON P.B. \& L.H. RIESEBERG 2009. The frequency of polyploid speciation in vascular plants. Proceedings of the National Academy of Sciences 106(33): 13875-13879. https:// doi.org/10.1073/pnas.0811575106

XU S.Q., SCHLÜTER P.M., SCOPECE G., BREITKOPF H., GROSS K., COZZOLINO S. \& F.P. SCHIESTL 2011. Floral isolation is the main reproductive barrier among closely related sexually deceptive orchids. Evolution 65(9): 2606-2620. https://doi.org/10.1111/ j.1558-5646.2011.01323.x

XU S.Q., SCHLÜTER P.M. \& F.P. SCHIESTL 2012a. Pollinator-driven speciation in sexually deceptive orchids. International Journal of Ecology. 2012, 285081. https://doi.org/10.1155/2012/285081

XU S.Q., SCHLÜTER P.M., GROSSNIKLAUS U. \& F.P. SCHIESTL 2012b. The genetic basis of pollinator adaptation in a sexually deceptive orchid. PLoS Genetics 8: e1002889. https://doi.org/10.1371/journal.pgen. 1002889

YAKIMOWSKI S.B. \& L.H. RIESEBERG 2014. The role of homoploid hybridization in evolution: a century of studies synthesizing genetics and ecology. American Journal of Botany. 101(8): 1247-1258. https://doi.org/ 10.3732/ajb.1400201

YANG R., FOLK R., ZHANG N.N. \& X. GONG 2019. Homoploid hybridization of plants in the Hengduan mountains region. Ecology and Evolution 9(14): 83998410. https://doi.org/10.1002/ece3.5393

YUAN Y.W., BYERS K.J.R.P. \& H.D. BRADSHAW JR 2013. The genetic control of flower-pollinator specificity. Current Opinion in Plant Biology 16(4): 422428. https://doi.org/10.1016/j.pbi.2013.05.004

ZHANG K., WANG X.W. \& F. CHENG 2019. Plant polyploidy: origin, evolution and its influence on crop 
domestication. Horticultural Plant Journal 5(6): 231-239. https://doi.org/10.1016/j.hpj.2019.11.003

ZIMMERMAN E.C. 1970. Adaptive radiation in Hawaii with special reference to insects. Biotropica 2(1): 32-38. https://doi.org/10.2307/2989786

\section{Appendix1: Some terminologies related to speciation}

Phyletic speciation: One species gradually transforming into a new species by accumulation of variations. Phyletic speciation does not increase biological diversity as it does not increase the number of species.

Divergent speciation/Cladogenesis: One species giving rise to two or more species and thus results in phylogenetic branching of the species. All the species resulting from cladogenesis may exist at a given time or any of them may become extinct at some point. Cladogenesis increases the number of species and thus biological diversity.

Phylogenetic tree: Is a diagram that shows an inferred (from fossil, and morphological and molecular evidences) path of evolution and evolutionary relationships between species. The node in a phylogenetic tree represents the common ancestor.

Sister species: Sister species are the two species derived from a common ancestral node. They represent each other's closest relatives since they share an ancestral species not shared by any other species.

Clade: A clade is a monophyletic group of organisms that includes all descendant species from a common ancestor (both extinct and extant).

Adaptive radiation: Speciation in which a species diverges rapidly into many species in comparatively a short time. This generally happens when a species enters a new habitat where there is little or no competition or environmental stress. Speciation through adaptive radiation is common in volcanic islands. When one or a few seeds arrive on these islands from the mainland, the initial population (founding population) is made up of an extremely small gene pool. The plants are free from predation by herbivores and of pathogens or from competition from other plants. The population multiplies rapidly and builds up the gene pool. When they spread to neighbouring islands, the populations of each island adapt to local conditions and evolve into new species.

Some examples of adaptive radiation: The Hawaiian group of silverswords consists of twenty eight species under three genera, Debautia (21 species), Argyroxiphium (5 species), Wilkesia (2 species), which include trees, shrubs, vines and cushion plants occupying different habitats. All available evidences indicate that all species of this group are the descendants from one species that arrived on Hawaiian islands millions of years ago (Baldwin \& Sanderson, 1998). Another remarkable example of adaptive radiation is the species of Drosophila on Hawaiian Islands (Zimmerman, 1970; Ashburner et al., 1981). Over 500 species of Drosophila are estimated to be present on these Islands and evidences indicate that all of them have evolved from one or two original founder individuals. Fifty six species of honeycreepers (birds) on Hawaiian Islands, (some of which have become extinct) (Olsen, 2004) and 14 species of Darwin's finches on Galapagos Islands (Petren et al., 2005) are also well known examples of adaptive radiation.

Genetic drift: Genetic drift is a random process that leads to large changes in the allelic composition of populations over a short period of time. Many of the alleles may get eliminated from the population irrespective of their role in the fitness of individuals. A few individuals of the population that survive may start recovering but their allelic composition would be different from the original population.

Ecotype: An ecotype is a genetically distinct geographic variant/population/race of a species which is adapted to specific environmental conditions. Phenotypic differences of ecotypes are of minor nature or too subtle to warrant classifying them into subspecies. Ecotypes are able to interbreed with other ecotypes without the loss of fertility or vigour.

Microevolution: Genetic variations in the population leading to the evolution of new varieties and species through selection of individuals or random drift.

Macroevolution: Evolution of taxonomic hierarchy above species levels (families, orders etc.) that evolve over millions of years. 